\title{
Strange DNA: The rise of DNA Analysis for Family Reunification and its Ethical Implications
}

\author{
MARTIN G. WEISS ${ }^{1}$
}

\begin{abstract}
DNA analysis for family reunification is a longstanding and widespread practice, but also a highly problematic one, as it is a battleground of conflicting values and interests, which have to be carefully weighed against each other: on the one hand, the right of the sovereign state to regulate immigration and prevent fraud and child trafficking; on the other hand, the right to privacy and family life. Beyond the problem of how to balance these different interests, DNA analysis for family reunification brings up the broader problem of biologisation/geneticisation of social relations, as this practice appears to reduce family to its mere biological notion. As there is no comprehensive account of the ethical implications of DNA analysis in the context of family reunification, the present paper will try to fill this gap by addressing the three most striking ethical problems posed by this issue: the privacy issues at stake; the problems concerning the conceptual, legal and social definition of family; and the question whether this practice intends to produce the immigrant as discriminated "bare life" (Agamben) or must rather be seen as a symptom of an ongoing general biologisation/geneticisation of sociality, also influencing family reunification procedures.
\end{abstract}

\section{Introduction: Tales of hope and despair}

As early as 1985, when DNA fingerprinting and genetic analysis were still highly contested techniques in forensic practice, Nature carried a report entitled 'Positive identification of an immigration test-case using human DNA fingerprints '.2 The authors describe a case in which a Ghanaian boy who was born in the UK but went to Ghana on a visit was denied return to the UK - where his mother and siblings lived on the grounds of suspected substitution of the boy with a nephew or a totally unrelated child. The family's lawyer asked for a DNA analysis to establish the parentage of the boy. The test demonstrated that the woman was in fact "the true mother" 3 , so the immigration agency dropped the case and the boy was permitted to return to the UK and to be reunited with his family.

But there are Ghanaian DNA analysis tales with less happy endings. In 2007, the New York Times published the story of Issac Owasu, a widower and naturalised US citizen of Ghanaian origin who also resorted to DNA analysis to accelerate his reunion with his four sons still living in Africa. "But modern day science often unearths secrets long buried. When the DNA results landed on Issacs Owusus's dinner table [...], they showed that only one of the four boys [...] was his biological child. [...] The State Department let his oldest son, now 23, come to the United States [...], but said the others - a 19-year-old and 17-year-old-twins - could not come because they are not biologically related to him." 4 
The strange molecule DNA, said to contain the essence of the human being, ${ }^{5}$ was from a very early stage focused on the DNA of the stranger, the immigrant, the asylum-seeker, eager to prove his or her genetic-biological ties in order to be eligible for immigration.

The term 'family reunification' refers to the right of family members living abroad to join relatives who hold long-term residence permits in a given country. While this right has previously been an integral part of many countries' immigration policies, the current trend among host countries seems to favour more restrictive family reunification policies. Many countries are imposing stricter requirements on those applying to enter the country, requiring them to provide official documentation to prove their identities (birth and marriage certificates, passports, etc.). Providing such information is often difficult, especially for those travelling from countries that do not use official documents to establish identity, or where the documents have been lost or destroyed due to politically unstable situations. But even if applicants do possess the required documents, the information is sometimes rejected by immigration authorities who question the authenticity of the documents. In this context, many countries resort to DNA analysis to resolve cases in which they consider the information presented concerning family relations to be incomplete or unsatisfactory. ${ }^{6}$

Although the exact number of cases in which DNA evidence is used for immigration purposes is not disclosed by the governmental agencies in most countries, available evidence indicates that the use of genetic testing within the context of immigration is on the increase. At least 17 countries have incorporated the use of DNA testing into decision-making on immigration: Australia, Austria, Belgium, Canada, Denmark, Finland, France, Germany, Italy, Lithuania, the Netherlands, New Zealand, Norway, Sweden, Switzerland, the UK, and the USA.

In the UK, according to one report, in the 10 years after the first use of a DNA test in a family reunification case in 1985, "DNA fingerprinting was used to test more than 18,000 immigrants who had been refused entry into the UK. Of these, more than 95 per cent produced results that showed they were blood relatives of UK citizens and were therefore entitled to British citizenship."7

Despite its relatively long history, increasing use and highly problematic aspects, there is still very little academic research on this topic, especially concerning the ethical implications underlying the practice of DNA analysis for family reunification. The studies published so far treat the issue mostly from a legal point of view or with a focus on specific national contexts. ${ }^{8}$

Drawing on first results from the interdisciplinary and multinational project DNA and Immigration ${ }^{9}$ and focusing on the German situation where the longstanding practice of DNA analysis for family reunification has only recently been regulated (by the Gendiagnostikgesetz (Act of Genetic Diagnostics) enacted in February 2010), I will attempt to focus on so far underexplored aspects, especially privacy issues. I will also 
look at the changes in the notion of family which, as a result of advances in biotechnology, seems somehow trapped between geneticisation and de-biologisation.

\section{Privacy and genetic privacy}

\section{The birth of privacy from the spirit of liberalism}

"The scholarly literature prescribing ideal definitions of privacy is extensive and inconclusive." "10 Although Anita Allen is probably right, we cannot forego the notion of "privacy", which is one of the most important concepts not only in contemporary ethics but also in legal codes, and is a central ethical issue for the use of DNA analysis for family reunification.

The 12th Article of the Universal Declaration of Human Rights states: "No one shall be subjected to arbitrary interference with his privacy, family, home or correspondence, nor to attacks upon his honour and reputation. Everyone has the right to the protection of the law against such interference or attacks." ${ }^{.1}$ This emphasis on privacy as a fundamental principle for society is a relatively modern concept. For some of the earliest political thinkers, such as Plato and Aristotle, the human being was primarily a political animal. However, Aristotle was realistic enough to see that politics, or the polis, understood as the open space of uncoerced discussion between free and equal individuals, has a material basis: the oikos, i.e., the house or family. According to Hannah Arendt, in the ancient world the private sphere, the oikos, had the function of guaranteeing the survival of the individual and the species. The oikos merely provides the basis for biological life, which is subordinated to the necessity of meeting natural needs. The fact that the oikos is simply the realm of natural animal life is reflected in the internal structure of the household, where the authoritarian pater familias exercises absolute power. In contrast, in the realm of the polis freedom and autonomy can be realised,

Aristotle himself stressed that in the realm of the oikos the lord is not free either, but like everyone else is bound by the necessity of survival. In the private sphere of the oikos, the human being is still an animal and not yet a political animal; that is, not yet fully human, if to be human means to be free and to make responsible choices. In the words of Hannah Arendt:

According to Greek thought, the human capacity for political organisation is not only different from but stands in direct opposition to the natural association whose centre is the home (oikia) and the family. The rise of the city-state meant that man received 'beside his private life a sort of second life, his bios politikos. Now every citizen belongs to different orders of existence; there is sharp distinction in his life between what is his own (idion) and what is communal (koinon)'. It was not just an opinion or theory of Aristotle but a simple historical fact that the foundation of the polis was preceded by the destruction of all organised units resting on kinship $[\ldots] .{ }^{12}$

Whereas, according to Arendt, for the ancient Greeks freedom was essentially 
exercised in the public sphere (polis), for modern liberalism - the political ideology on which Western liberal democracies are based - the genuine place of freedom is private life (oikos). Public or state interference in this sphere can be justified only when absolutely necessary to preserve the freedom of the individual person. ${ }^{13}$

But if humanity consists in exercising the ability freely to choose what the human being considers to be the best for him/herself, this choosing must take place undisturbed by the outside (and inner) world. Freedom necessitates isolation from inner (emotions, effects, physical needs) and outside interference. Thomas M. Cooley consequently asked for a "right to be let alone". ${ }^{14}$ In their essay "The Right to Privacy', which might be said to mark the starting point of the discussion on privacy, Brandeis and Warren state, with reference to Cooley: "The intensity and complexity of life, attendant upon advancing civilisation, have rendered necessary some retreat from the world, and man, under the refining influence of culture, has become more sensitive to publicity, so that solitude and privacy have become more essential to the individual." 15

Of special interest in the context of DNA analysis for family reunification is the fact that in decisions of the Supreme Court of the USA, US family life was from a very early stage included in the notion of privacy. ${ }^{16}$ This is, incidentally, in line with liberal theory which sees privacy in concentric circles around the individual person, so that home and family are situated near the centre of individual privacy, i.e., the core value of liberalism.

Although different concepts of privacy have been under attack from different sides ${ }^{17}$ ranging from the rather eccentric efforts to dissolve it into a myriad of particular interests, ${ }^{18}$ through attempts to reduce privacy to liberty,${ }^{19}$ and finally the feminist critique, which sees privacy as a subtle disguise to cover up private violence ${ }^{20}-$ the right to privacy is an established and widely acknowledged moral right, although explanations of what exactly privacy means are still under discussion. Whereas authors like Edward J. Bloustein, located in the classical liberal tradition, identify privacy with human dignity ${ }^{21}$, Charles Fried ${ }^{22}$ and W. A. Parent ${ }^{23}$ agree in their definition of privacy as control over personal information, i.e., as the right of the individual to decide which information about herself may be made available to others and under what circumstances, but they differ in the rationale that they give for the importance of privacy.

\section{Genetic privacy in a non-medical context}

\section{Genetic exeptionalism}

In the context of privacy, at least since the start of the Human Genome Project, genetic privacy has received special attention and a demand has been made for a genetic exceptionalism, stating that genetic data merits special protection. The special danger for personal privacy deriving from the access to one's genetic information arises from the exceptional nature of this information which concerns the biological conditions of personal existence. Genetic material contains information not only about 
one's physical phenotype and (allegedly) behavioural traits (or at least the probability of their expression), but also information about the likelihood that a person (and her kin) will develop specific diseases. The possibilities of a misuse of this data are extensive, ranging from the denial of private medical insurance to disadvantages on the labour market.

Anita L. Allen distinguishes "informational, decisional, physical, and proprietary dimensions" 24 of genetic privacy. According to Allen, genetic privacy is normally associated with informational privacy in the sense of "the claim of an individual to determine what information about himself or herself should be known to others" 25 based on the notion of individual autonomy or self-determination.

The genetic privacy concerns heard today range far beyond informational privacy to concerns about physical, decisional, and proprietary privacy. Briefly issues of physical privacy underlie concerns about genetic testing, screening, or treatment without voluntary and informed consent. In the absence of consent, these practices constitute unwanted physical contact, compromising interests in bodily integrity and security. Decisional privacy concerns are heard in calls for autonomous decision making by individuals, couples, or families who use genetic services. A degree of choice with regard to genetic counseling, testing, and abortion are a requirement of respect for decisional privacy. The fourth category of privacy concerns proprietary privacy, encompasses issues relating to the appropriation of individuals' possessory and economic interest in their genes and other putative bodily repositories of personality. ${ }^{26}$

The notion of genetic exceptionalism has been challenged on the grounds of the difficulty of conceiving genetic information independently from other medical information, ${ }^{27}$ as well as with reference to the paradigmatic skip from genetic determinism to genetic probabilism, which sees genetic information not as an imminent destiny, but as a manageable risk or even chance. ${ }^{28}$ But risk is no less frightening than destiny, as the discussion about the right not to know genetic predispositions has shown. Although the notion of genetic determinism has been abandoned, knowing one's risk is no less troubling than having a certainty, as the knowledge of predispositions to illnesses or hereditary diseases may have a deep impact on the psyche and the way in which one conducts one's life. The supporters of a right not to know base their opinion on the argument that the individual should have the choice to live her life unencumbered by the knowledge of having a greater risk (or even certainty, as in the case of Huntington's Disease) of developing a disease later in life. The individual should decide by herself whether or not she wants to know about her risk of suffering from a particular condition. ${ }^{29}$

In fact, in the age of generalised genetic tests, mere probabilities have become less and less distinguishable from facts. ${ }^{30}$ As Nikolas Rose has shown, nowadays genetic predispositions to certain illnesses produce the same consequences as the illness itself, so that there is no longer a distinction between "pre-symptomatic patients" and actual 
patients, blurring the Aristotelian distinction between potentiality and reality. The mere predisposition to a certain illness, where the person "feels" completely healthy and doesn't show any symptoms, may lead to the same consequences that the outbreak of the illness would. This is best illustrated by the "treatment" of pre-symptomatic breast-cancer patients: two-thirds of the women diagnosed as having the mutated allele in their genome, which "raises their risk of developing breast cancer sometime in their lives to between 60 and 90 per cent" 31 , decide to undergo preventive surgery.

\section{Excess data in a non-medical context}

Moreover, DNA fingerprinting may produce excess data - meaning data about predispositions and probabilities of gene expression - the collection of which may not be explicitly intended but nevertheless occurs. Given the unforeseeable evolution of genetics, it is not possible to say what information may be revealed through specific DNA data in the future, so the claim that DNA fingerprinting can be used only for identification and does not disclose anything else about a person is merely speculative, as the discovery of the unexpected important function of 'junk DNA', which for a long time was thought to contain no information at all, has shown. ${ }^{32}$ We simply do not know what information a given genetic data set may reveal in the future. In addition, Amade M'charek has drawn attention to the fact that there are tendencies in (forensic) DNA fingerprinting to substitute non-coding DNA with coding DNA to infer the possible phenotypic appearance of suspects. ${ }^{33}$ In this regard, genetic exceptionalism still seems to be justified.

Special attention has been given to the importance of privacy in the context of medical intervention. The storage of genetic material or genetic information here is allowed only with informed consent, fundamental in the medical context. This consent normally has to be given in writing and serves to ensure that the person concerned is informed about the amount, nature and scope of the collection and processing of her data. The forms on which the informed consent is recorded have to specify that the consent is voluntary and can be retracted at any time, and what (legal) consequences a refusal to give consent may imply.

Informed consent given under coercion is invalid. ${ }^{34}$ Furthermore, the large body of literature on informed consent in the medical sphere stresses that the way in which the patient is advised in order for them to be able to give a truly informed consent should not assume an ideal, reasonable person, but must take into account the specific situation of the actual person whose consent is desired. Thus, it is ethically not sufficient to provide the related information about the meaning and possible consequences and alternatives in a way that an average person (or even worse, an average physician) would understand, but in such a way that the person involved is able to understand to what she is consenting. It is probable that this sort of ethically sound information on the meaning, the possible alternatives and the consequences of a DNA analysis to assert a genetic relationship may be especially difficult in the context of family reunification cases where the concerned persons come from different cultural backgrounds and may often have very little previous knowledge on genetics. 
In the context of DNA analysis for family reunification, extremely sensitive data may be collected, handled and stored not in a medical context, where it will be regulated by strict ethical frameworks and professional ethics to prevent misuse, but in an administrative context where such standards are not always met. A telling example for the problems posed by the handling of genetic data outside the medical context is the legal regulation of DNA analysis for family reunification in Germany by the Gendiagnostikgesetz (Act of Genetic Diagnostics). The focus of this law is on the right of informational self-determination, with the aim of protecting individuals from the abuse of their genetic information. However, some important legal guarantees do not apply for the use of genetic data gathered in the context of family reunification. For example, immigrants can neither demand that their genetic data and samples be destroyed, nor prevent the possibility of their data or samples being used for criminal prosecution purposes.

In a statement delivered in a hearing at the German Bundestag the German charity Pro Asyl, an organisation devoted to assisting asylum seekers, criticised the law, It said that the law, originally designed to protect nationals against misuse of their genetic data or samples in the medical context, in fact strips immigrants of this very protection by explicitly denying applicants for family reunification those rights. When it comes to DNA analysis for family reunification the Act explicitly denies the applicants the right to retract their consent, the right to have their data and samples destroyed, the right not to have their data used for secondary purposes (mainly forensics), and the right to be informed or, conversely, the right not to know, about the possible health risks (including the possible psychological shock of learning that alleged relatives are not biologically related). ${ }^{35}$ The double standard thus created in the treatment of personal data and genetic samples of immigrants and residents can hardly be justified by the legitimate interest of the state in preventing illegal immigration, including human trafficking.

\section{Genetic privacy and children's rights}

An especially delicate area is the treatment of children. In the bioethical literature on informed consent and children there is broad consensus that as far as possible even very young children must be included in decision-making processes regarding medical intervention, and that the actual psychological and physical development of the children involved must be taken into account. Even small children may be involved in the decision-making process if they are able to understand what it is about. It is reasonable to assume that this consensus also extends to decision-making processes regarding the genetic information of children. In the case of DNA analysis for family reunification, it is not possible to bypass the need for informed consent of the children by resorting to the consent of the parents, on the simple logical grounds that before the test the alleged parents cannot be considered the legal parents of the child - the entire aim of the DNA analysis is to establish that they are biologically the parents of the child. In order to perform DNA analysis on immigrant children the state has - at least on a conceptual level - first to claim custody of the child and then 
consent that the state performs the DNA analysis on its foster child. Although this procedure involves different government agencies, it remains problematic that the state acts both as legal guardian and immigration authority.

As mentioned above the concept of privacy - centered around the singular individual - from a very early stage of its discussion included the family, which is widely identified with the private and secure space necessary for the free development of the individual. This liberal idea of an intrinsic connection between individual freedom and family led to the formulation of the human right to family life and consequently to the right to family reunification nowadays often achievable only through DNA analysis. But what notion of family underlies this praxis and more generally, what does it mean to be a family in an age in which family relations seem to be demonstrable through genetic analysis?

\section{Family concepts}

\section{Dual standards in the definition of family}

Several studies have demonstrated that the core family is a contingent notion in both diachronic and synchronic terms. ${ }^{36}$ But even accepting the plurality of family definitions in time and among different cultures, one could still argue that immigrants, whatever the definition of family in their culture of origin, should accept the definition of family held by the society that they want to, or have to, live in. Put bluntly: if an immigrant or refugee wants to, or has to, live in a Western democracy, she will have to adapt to the laws and customs of that society, including its definition of family. But the adoption of the common definition of family in Western liberal societies is exactly what is denied to immigrants applying for family reunification in most countries, as the majority of Western liberal societies share a pluralistic and mostly socially defined notion of family, including patchwork families, adopted children, and same sex families, yet this definition is denied to immigrants who have to resort to DNA analysis to apply for family reunification. Even in countries where the right to family reunification encompasses more than the core family, the possibility to reunite with family members not linked by consanguinity remains largely hypothetical, as the necessary documentation to prove kinship is often rejected as insufficient by the immigration authorities. Germany, for instance, does not generally accept any documents on family status from 40 countries. ${ }^{37}$ Thus despite other provisions DNA analysis often represents the only possible route to family reunification.

The practice of DNA analysis for family reunification implies that only biological relatives are eligible for family reunification and excludes all family members who are related socially. This requirement of a biological link between family members is diametrically opposed to family recognition policies in many host countries, which emphasise social rather than genetic ties. ${ }^{38}$ This results in the ethical problem that a "dual standard of family recognition" is established for native citizens and immigrants. ${ }^{39}$ This focus on genetic links also means that alternative forms of family are devalued and seen as secondary; they are not recognised as "true" family ties. 


\section{The family between de-biologisation and re-biologisation}

The use of DNA analysis for family reunifications, then, fails to take into consideration not only the different definitions of family of the immigrant/refugee culture, but also the definition of family generally pertaining in liberal democracies, which has undergone a dramatic transformation in recent times:

Parenthood was understood to be largely a natural relation founded upon biological reproduction, and a legal status as a parent followed easily from recognition of that natural fact [...]. Recently, however, the changes sweeping over the rest of family law have caught up to parenthood as well. Biology is increasingly called upon to share its privileged status as the foundation stone of parenthood caregiving and other social values. Legal parenthood without genetic connection, marriage, or adoption is now a reality in several U.S. States. Proposals to expand the numerical boundaries of parenthood, so that a child might have at once three, four, or even more parents, now carry the imprimatur of the United States' most influential lawreform organisation [The American Law Institute].

So although Western societies are embracing more and more liberal definitions of family, abandoning the biological concept of family, their immigration policies contradict this general tendency because, although the legal frameworks may allow for the possibility to reunite with family members who are not biologically related, the strict guidelines regulating which documents are accepted as proof, transform DNA analysis for family reunification - originally intended as a last resort - into the standard procedure. ${ }^{41}$

On the one hand, this biologisation of the family strengthens its traditional social function (procreation) and structure, as (married) partners can prove that they are "truly" related only through their biological offspring, which become the "material proof of their conjugal love", a notion echoing and performatively naturalising ${ }^{42}$ the traditional (Christian) definition of marriage. The implicit preconception of family is that of the nuclear family composed of two heterosexual parents and their biological children, a model which even in Europe was established only in the $18^{\text {th }}$ century and is losing more and more ground in a period when patchwork families and homosexual partnerships are widely accepted. ${ }^{43}$ By reducing the immigrant family to biological ties, the practice of genetic testing for family reunification promotes the hetoronormativity of the nuclear family. ${ }^{44}$ Furthermore, the return of the distinction between legitimate and illegitimate children, implicit in the current practice of immigrant family reunifications, is at the very least anachronistic, and is arguably in contrast to the views of the general public in Western societies. In an attempt to mitigate this anachronistic effect, in France the law does "not test paternity in order to avoid embarrassing revelations about fidelity in past relationships", 45 but only the biological kinship between mother and child.

On the other hand, the geneticisation of family resulting from the practice of DNA analysis for family reunification could be seen as part of a relatively new tendency 
towards a general biologisation of human relations also visible in the emergence of consumer genomics ${ }^{46}$ and forms of "biological citizenship" 47 or "genetic citizenship". ${ }^{48}$

\section{De-biologisation through biology?}

It is important to emphasise that this geneticisation of the family does not stem from genetics: it is precisely genetic and reproductive technologies that undermine the idea of parenthood as a natural relationship founded on biological relations, since they make it possible to distinguish systematically between biological parents and those who rear and educate a child, thus highlighting the limitation of the mere biological concept of parenthood, also reflected by the law and judiciary in the USA:

In the realm of assisted reproduction [...] the law for several decades now has permitted the conferral of legal parenthood without adoption and without any true pretense of a biological connection. Since the Uniform Parentage Act of 1973, the law in most jurisdictions has provided that a child born to a married woman, as a consequence of artificial insemination from a donor other than her husband, is legally the husband's child [...] The sperm donor is dealt out of the picture entirely, even though he is known to be the genetic father of the child. ${ }^{49}$

The basis for granting parentage here is not biology but the intentions of the people involved, so that it is not the surrogate mother, sperm or egg donor (the biological parent) who is considered to be the "true" parent, but the persons who demonstrate their "procreative intentions" and intend to raise the child, independently of whether this person is biologically related to the child. What is decisive is the "procreative intent" and not biological or genetic relatedness. ${ }^{50}$ The weakening of the biological notion of parenthood is also visible in the US states that permit some form of samesex marriage, as there the partners "can avail themselves of a presumption of parentage based on the traditional marital presumption, though without of course any supposition that it reflects an inference of biological parenthood."

In 2000, the American Law Institute recommended the recognition of parents by estoppel and of de facto parents. "The revised Uniform Parentage Act therefore acknowledges the importance of a social-parental relationship that is more important than the genetic relationship in the best interest of a child over two years old." 52 The new possibilities of assisted procreation are, paradoxically, strengthening the social conception of family and parenthood. In the context of assisted procreation, neither the sperm donor (the genetic father), nor the egg cell donor (the genetic mother), nor (in cases of surrogate motherhood) the childbearing woman is considered to be the legal parent of the child, but only the social parents, on the grounds of their manifest intention to take care of the artificially conceived child.

\section{Re-biologisation through culture?}

Although these developments at first glance seem to weaken the biological notion of family, biology or at least the imitation of biology still plays an important role in the 
attribution of non-biological parenthood. In the USA, according to Meyer:

The law often reflected an assumption that adoptive parents were second-best 'stand-ins' in circumstances where the 'real' - i.e., biological - parents were simply unavailable. At one time, it was customary for judges and caseworkers to place great importance on 'matching' a child to prospect adoptive parents who shared the same ethnic, religious, and cultural background. Considerable effort was expended to ensure that the child physically resembled the adoptive parents, so that outsiders (or even the child) would not suspect that the family had been created by adoption Although adoptive parents were accorded full parental status ... traditional adoption law and practice nevertheless implied that the legitimacy of the adoptive relationship turned in some sense on its ability to mimic a biological one. $^{53}$

The same is true for egg cell donation, where prospective parents and clinics are preoccupied with securing the greatest resemblance between the donor and the prospective mother. ${ }^{54}$

Thus, one has to acknowledge opposing trends: on the one hand an ongoing weakening of the biological notion of family (due at least in part to newest developments in reproductive technologies), and on the other hand a growing tendency to link parenthood to biological ties, evident in other legal developments. So the possibility of a disestablishment of paternity on the grounds of a lack of biological relatedness is possible even after several years of effective social fatherhood. ${ }^{55}$ Furthermore, "Courts have held men liable for support arrangements accruing during years when they were entirely ignorant of the children's existence - that is, when they were not legal parents at all., 56

A creeping re-biologisation of parenthood is reflected by the growing number of US states allow the genetic father to establish legal "parentage of a child born of a married woman, even over the objections of the mother's husband. The readiness of these jurisdictions to reassign parental status on receipt of a DNA match, even when that means extinguishing a substantial pre-existing parent-child bond, reveals a reflexive commitment to biology as the essential foundation of parenthood." ${ }^{, 57}$

Another example of increasing biologisation is the abandonment of secrecy in donor insemination in most countries in recent times. ${ }^{58}$

But where does this renewed interest in biological origin come from? Why the shift from anonymity to openness? "At a broader socio-cultural level, identity itself has been redefined. With the democratisation of genomic knowledge through the print and electronic media, particularly the internet, genes have become central to 'real' or legitimate identity and important determinants of health and behavior." $" 59$ Independently of the medical or psychological importance attributed to knowledge about one's genetic ancestors, the desire to know one's biological origins is a 
preeminent current cultural phenomenon. As "social fact" genetic origin is very real and has very real consequences at the level of social relations. For example, a paternity testing study carried out in Australia "revealed that most men who found out they were not the biological father believed that their changed paternal status removed their right to be the father. Although legislatively they could assert this right, they believed that, being scientifically proven not to be the biological father of a child they had raised, they no longer could or should claim paternal rights." 60

Although one anticipated result of the Human Genome Project, to discover particular genes for specific phenotypic features - an idea based on the one-gene-one-proteinhypothesis - was not achieved, popular culture and society continue to cling to genetic determinism and have barely taken notice of the ongoing epigenetic shift in genetics. This shift has lead to a redefinition of the gene, which is now no longer conceived as the master molecule containing the program for the expression of specific proteins, but as a complex feedback system involving the entire cell (genes and cell plasma) and its environment.

The relationship between culture and society on the one hand and biotechnology and genetics on the other is more complicated than it seems at first glance. The newest developments in biotechnology, mainly in reproductive technology, have led to a weakening of the biological notion of family, while a lack of genetic knowledge seems to be the reason for a strengthening of biologism in popular culture and society, leading for instance to "a rapid re-conceptualisation of paternity secrets from being protective of children and families to being 'a harmful subterfuge likely to damage a child emotionally and psychologically'." ${ }^{\prime \prime 1}$ Whereas the application of biotechnology, particularly reproductive technologies, seems to lead to a weakening of the biological notion of family, the lack of biological knowledge seems to lead to the rebiologisation of parenthood.

Re-biologisation is not limited to popular culture, but has also infiltrated academic institutions such as the German National Ethics Committee. In a highly controversial decision, the Committee, (established as a counselling body for the German parliament and administration) advocated the closure of facilities for the anonymous relinquishing of newborns. The Committee's judgment was based not only on empirical studies suggesting that such facilities do not prevent infanticides, but also on an alleged fundamental human right to know one's biological/genetic origin: "A child has a right to his physical and psychological integrity. Since ignorance of one's parentage can be severely prejudicial to the development of a person's identity and give rise to profound psychological disturbances, this fundamental right of the child must be included in the considerations of the relevant merits." 62

What the recommendation fails to consider is that in most cases these children have caring parents whom they know very well, even though these are not their biological parents. Whereas an earlier rationale was based on the assumption that it is in the best interest of the child (mainly to save her from psychological distress) not to reveal that she was adopted or the result of artificial procreation technologies, be it donor 
insemination, ovum donation, surrogate motherhood or a combination of these techniques, in the age of genetic truth to know one's biological origin has become an unquestionable imperative, as it is conceived as the feature defining personal identity and autonomy.

But if knowing one's genetic origin is truly so essential for psychological health and personal identity, as the German Ethics Committee and a growing sector of German public opinion seem to maintain ${ }^{63}$, and given the fact that according to new studies at least 2-4 per cent of fathers in Western countries are (mostly without knowing it) not the biological father of "their" children, ${ }^{64}$ why then not be consequent and advocate a general screening of all newborns and their alleged parents to determine if they are really the "true" parents? This simple thought experiment not only shows the untenable nature of the committee's position, but also that the practice of DNA analysis for family reunification establishes a dual standard in family recognition. Most of us would probably vehemently reject a generalised screening of all newborns to verify their kinship with their parents; but it is exactly this that is done with immigrants.

What is entirely denied in this duty to genetic truth is the right not to know. This may be connected to the general tendency towards the imperative of self-governance and self-management reflected in the concept of "biological citizenship".

\section{Biological citizenship as subjectivation between empowerment and domination}

\section{DNA analysis for family reunification as domination}

The shift from paternalism to autonomy in biomedicine has not been limited to personal autonomy, but has lead to a new form of citizenship: "biological citizenship", a term indicating the group-defining role of biological properties. Groups of persons base their identity on particular medical conditions or specific biological/genetic features, often in connection with claims for special rights or benefits. These "biosocialities" 65 are organised in often powerful support and patient groups engaged in fundraising and lobbying to promote specific research agendas and promising treatments, and represent a new form of active "patients" facing the biomedical establishment as equal partners. Used in this sense, the term "biological citizenship" dates back to Adriana Petryna's study Life Exposed. Biological Citizens after Chernobyl, ${ }^{66}$ in which she examined the emergence of a new form of citizenship based on the health problems caused by radioactive contamination. According to Petryna, this biological identity also played a crucial role in the rise of an independent Ukrainian nation after the collapse of the Soviet Union. The important differences from modern biological group identity, according to authors such as Petryna, Nikolas Rose and Carlos Novas, lie in the empowering aspect of these new identities. In the past, alleged biological features - i.e. the products of naturalisations and performative discourses ${ }^{67}$ - were intended to stigmatise minorities and used to promulgate eugenic policies aiming to combat an alleged "degeneration" of the population by enhancing the biological fitness of the nation. The new biological group identity emphasises the responsibility of the individual subject and "pre-symptomatic" "pre-patient" 68 to 
manage his health and risky biology in his own interest. "What we have here, then, is not eugenics but is shaped by forms of self-government imposed by the obligations of choice ..."

However, in the context of genetic testing for family reunification, the notion of biological citizenship reveals an unexpected new aspect. In the existing literature, the idea of biological citizenship often stresses the democratic, anti-authoritarian and counter-hegemonic potential of this concept. But genetic testing for family reunification more closely resembles the old-fashioned practice of "subjectivation", meaning not self-governance but domination, as here it is the sovereign power that reduces the immigrant family to its animalitas, linking legal claims to biological facts. In this process alleged biological features such as race or ethnicity are implicitly attributed to the foreign "subject", because the genetic linkage between individuals always also connotes ideas of biological race, since DNA analysis for family reunification presupposes the concept of genetically different sub-populations. The authority here is held by an absolute sovereign power which is able to exercise domination. The decision to allow or refuse immigration in family reunification cases often comes close to the sovereign power over life and death, as family life is intrinsic to "good life" and is an undeniable human right whose denial harms human dignity.

From an Agambenian point of view, the use of DNA analysis in family reunification cases can be interpreted as highlighting the sovereign power hidden under the facade of liberal democracies. From this perspective, the practice of DNA analysis for family reunification resembles not a form of empowering biological citizenship but more "Biopolitics" in the sense Agamben uses this term, as here the "bare life" of the immigrant is actually produced by the political. In contrast to Foucault, for whom the inclusion of mere biological life in the realm of politics is the "threshold of modernity", according to Agamben politics was always Biopolitics, as for Agemben politics is characterised by the, somehow Hobbesean, dialectics of sovereign power over life and death and the potentially killable life of the "subject".

According to Agamben, and in contrast to the work of Arendt mentioned above, politics since its very beginning was based on the reciprocal constitution of absolute sovereign power and subjected citizens. Again in accordance with Hobbes, citizens are constituted as such in the very moment they become subjected to the sovereign power, which is the very same event through which sovereign power becomes what it is. This means that the killable life of the "subject", i.e. the citizen, what Agamben calls "bare life", is, as well as sovereign power, the product of politics and may not be confused with the mere biological life that Agamben terms "zoe". In fact "bare life" as a necessary element of the political sphere - without which there would be no sovereignty and therefore no political order at all - is nothing "natural".

Agamben distinguishes between (a) zoe, the mere biological substratum of the human life, (b) the specific human life-form, i.e. the form of life including thinking, speaking and sociality (bios), and (c) "bare life", i.e. the potentially killable life-form of the citizen. The confusion between zoe (conceptually antecedent to the political 
distinction between life-forms), and "bare life" as the killable life-form produced by politics, is due to the fact that the production of "bare life" in politics is performed by reducing the human life-form to mere biological life now defined as killable life. The wrong identification of zoe with "bare life" is provoked by the fact that the production of killable life-forms is regularly achieved by reducing human life-forms to mere zoe. But the "bare life" produced by the reduction of the human bios to mere biological life is not the same as simple biological life. The result of the reduction of the human animal to its animality is not the same as the animality which forms the biological basis of humanity. Thus "bare life" is not mere biological life, i.e. the biological substratum of humanity (zoe) but the result of the reduction of the human life-form (bios) to zoe. The mere life that forms the basis of the human animal (zoe) gifted with reason is not the same mere life that remains after the reduction of the rational animal to its animality ("bare life"). The first one is neither worth living nor killable, the latter is the killable product of politics.

\section{DNA analysis for family reunification as empowerment}

Admittedly, there is another possible reading of DNA analysis in the context of family reunification, relating it to self-empowering "biological citizenship", as the use of DNA testing for family reunification can be seen as an empowering tool in the hands of prospective immigrants who in the past would have had no chance at all to migrate. From the point of view of the immigrants, the use of DNA analysis in family reunification procedures is ambiguous. It could be seen as discriminating and criminalising - as we have seen in the German example where the law permits genetic data and samples of immigrants to be stored for forensic purposes "when criminal acts are suspected", ${ }^{70}$ but not that of nationals. However, it is possible to see it as empowering, as it not only enables people to apply for family reunification which they were previously generally denied, because of the difficulties of proving family ties by documentation in certain countries, but may also accelerate and simplify the entire immigration process. In a way similar to the ambiguous role that genetic knowledge and biotechnological achievements have played in the field of reproductive technologies for the (de)-biologisation of the family, the role of biotechnology is also ambivalent in the context of DNA analysis for family reunification.

From a Roseian point of view, one could interpret the advent of the new technology of DNA analysis, which replaces the older techniques of marriage documentation analysis and extended interviews with the alleged family members, as empowering. Applicants may actively prove their relationship by themselves and no longer need to be dependent on the good will of a civil servant who has to be persuaded that one is telling the truth. From this perspective, the use of DNA analysis for family reunification and the connected "biologisation" of the applicants can be seen as producing a form of empowering "biological citizenship".

\section{New truth machines}

It is important to emphasise, however, that the change in the techniques employed to 
decide family reunification cases implies a radical shift in the way that truth is produced, as with the new technique the body becomes a kind of biological lie detector. Whereas the conventional techniques (documentation analysis and interviews) finally lead to a decision by a human subject (an official or judge) over the truthfulness of another subject, and could therefore be right or wrong, the new technology (DNA analysis) does not produce judgements about subjects but declarations about statistical probabilities, which by definition can be neither true nor false. So to draw on the alleged facts of genetics paradoxically leads to an abandonment of facts. In the truth regime of DNA analysis, a positive genetic test does not establish whether the alleged family members are actually related, as the results of such a test are never 'true' but only 'probable'. What is observable in the differences between these two truth regimes is the difference between our everyday "life world" (Husserl) and the abstraction of scientific facts.

This difference leads to the greater question of what meaning information about genetic predisposition - that is the probability that one will contract a certain illness by a certain age - can have for us. What does it mean for a 40 -year-old person to have a 60 per cent increased probability of developing heart failure by the age of 80 ? What do we do with this kind of information? Although this question deserves a much deeper analysis, beyond the scope of this paper, we hope that this paper gives an idea of the principal uncertainties produced by the introduction of DNA analysis in the context of family reunification, because in order to provide information about probable genetic relationships (with "negligible" error margins) it is necessary to abandon "truth".

Beyond these epistemological differences between the old techniques of document analysis and interviews on the one hand and DNA analysis on the other, it has to be emphasised that from an ethical standpoint the older techniques are probably no less problematic than DNA tests, because their potential to harm personal privacy is equally enormous, especially when intensive interrogation techniques are used on children. Interviews are not automatically the ethically less challenging technique, as Murdock seems to suggest. ${ }^{72}$

Although it may be less expensive to interview children than to carry out DNA tests, as Murdock claims (a dubious claim, incidentally, given the ever-decreasing costs of DNA analysis), interrogations of children cannot be advocated. Interviews of this kind put the children under immense psychological pressure and may lead to worse harm than DNA analysis. An unexpected DNA test result ("true" or "false") may certainly severely harm family relations, but a negative decision by the immigration service based on the (maybe misinterpreted) interrogation of a child, resulting in the denial of family reunification, creates an intolerable burden on the child, who bears responsibility for the rest of his life for the separation of his parents. A false, i.e., misinterpreted, interview with a child is therefore ethically much more problematic than a false DNA analysis. In my view, interviews with small children should under no circumstances be part of family reunification procedures. 


\section{Conclusions}

DNA analysis for family reunification raises highly contested and widely discussed ethical and political issues, ranging from definitions of family and privacy to fair immigration practices and geneticisation. As we have tried to show, the use of DNA analysis for family reunification, and especially the way in which this technique is implemented, not only reflects ongoing transformations in our societies but also reveals how we conceive politics, family, and ourselves. The way in which we treat immigrants and asylum seekers can tell us a great deal about the society we are living in, about who we are and where we are going.

Our reflection upon the privacy issues posed by the use of DNA analysis for family reunification - especially those related to the handling of genetic data and samples in a non-medical environment and the unique problems posed by the involvement of children - has led us to considerations about the dual standards adopted by liberal democracies when it comes to defining immigrant families and domestic families. Whereas a resident family may assume diverse forms (patchwork families, same sex partnerships etc), an immigrant family is - by practice, if not as defined by law reduced to a mere biological relation, as proving family ties is often possible only by genetic analysis.

This prompted us to examine the role biology plays in the current interpretation of the family within our liberal societies. The analysis of conflicting tendencies within the legal and ethical discourse about the role of biology in defining family ties allowed us to formulate the hypothesis that the current situation represents a contemporaneity of two conflicting tendencies: on the one side what seems to be a growing tendency to re-biologise the family, seen particularly in popular culture and the media, and on the other side a contrasting tendency to de-biologise the family on the grounds of scientific insights.

Finally we explored the not less conflicting possible interpretations of DNA analysis for family reunification in the context of ongoing debates about biopolitics, mainly the question whether this practice represents a form of discrimination and biopolitical "subjectivation", producing the immigrant as "bare life" subjected to the sovereign power, or if DNA analysis could be interpreted as a form of empowerment of the applicant based on an explicit reference to his biology, which would transform DNA analysis for family reunification into a technique to achieve "biological citizenship".

\section{Acknowledgments}

The support of the Austrian Genome Research Programme (GEN-AU) and the Austrian Research Promotion Agency (FFG) is gratefully acknowledged. The work is part of the international research project DNA and Immigration (www.immigene.eu). I thank all members for their feedback. I thank also the colleagues of my Department for the discussion of the draft, Barbara Prainsack (Brunel University) for her comments and the anonymous reviewers for their constructive critique. 
${ }^{1}$ Department of Philosophy, University of Klagenfurt. martin.weiss@aau.at

${ }^{2}$ A. J. Jeffreys et al. Positive identification of an immigration test-case using human DNA fingerprints. Nature 1985; 317: 818-819.

${ }^{3}$ Ibid, p.819.

${ }^{4}$ R. L. Swarns. DNA Tests Offer Immigrants Hope or Despair. The New York Times 10 April 2007.

${ }^{5}$ M. Farrelly, B. Prainsack, and L. Mayblin, Book review: Truth machine: The contentious history of DNA fingerprinting, Critical Policy Studies 2008; 3 (1) : 141- 148

${ }^{6} \mathrm{~J}$. Taitz et al. The Last Resort: Exploring the Use of DNA Testing for Family Reunification. Health and Human Rights 2002; 6(1): 20-32.

${ }^{7}$ R. McKie. Eureka moment that led to the discovery of DNA fingerprinting. The Guardian 24 May 2009.

${ }^{8}$ J. D. Villiers. Brave New World: The use and potential misuse of DNA technology in immigration law. Boston College Third World Law Journal 2010; 30: 239-271; Th. Lemke et al. 2011. Die Nutzung von DNA-Tests in Einwanderungsverfahren: das Beispiel Deutschland. In Leben in Gesellschaft. Biomedizin - Politik - Sozialwissenschaften. J. Kehr and J. Niewöhner, eds. Bielefeld. Transcript: $143-$ 178; T. R. Murdock. Whose Child Is This?: Genetic Analysis and Family Reunification Immigration in France. Vanderbilt Journal of Transnational Law 2008; 41: 1503-1534; A. R. Davis. Are You My Mother? The Scientific and Legal Validity of Conventional Blood Testing and DNA Fingerprinting to Establish Proof of Parentage in Immigration Cases. Brigham Young University Law Review 1994: 129149; J. Taitz et al. DNA and immigration: the ethical ramifications. The Lancet 2002; 359: 794; J. Taitz et al. op.cit., note 6 .

${ }^{9}$ www.immigene.eu (accessed 18 November 2011)

${ }^{10}$ A. L. Allen. 1997. Genetic Privacy: Emerging Concepts and Values. In Genetic Secrets. Protecting Privacy and Confidentiality in the Genetic Era. M. A. Rothstein, ed. Nev Haven. Yale University Press: 31-59, p. 34.

${ }^{11} \mathrm{http}$ ://www.un.org/en/documents/udhr/index.shtml\#a11 (accessed 18 November 2011)

${ }^{12}$ H. Arendt. 1998. The Human Condition. Chicago. Chicago University Press, p. 24.

${ }^{13}$ J. St. Mill. 1983. On Liberty. Cambridge. Cambridge University Press.

${ }^{14}$ Th. M. Cooley. 1880. A Treatise on the Law of Torts or the Wrongs that Arise Independent from Contract. Chicago. Callaghan, p. 29

${ }^{15}$ L. D. Brandeis et al. The Right to Privacy. Harvard Law Review 1890; 4 (5).

${ }^{16}$ R. Bork. 1990. The Tempting of America: The Political Seduction of the Law. New York. Simon and Schuster.

${ }^{17}$ J. DeCew. 1997. In Pursuit of Privacy: Law, Ethics, and the Rise of Technology. Ithaca. Cornell University Press.

${ }^{18}$ J. Thomson. The Right to Privacy. Philosophy and Public Affairs 1975; 4: 295-314.

${ }^{19}$ W. A. Parent. Privacy, Morality, and the Law. Philosophy and Public Affairs 1983;12(4): 269-288.

${ }^{20}$ C. MacKinnon. 1989. Toward a Feminist Theory of the State. Cambridge. Harvard University Press.

${ }^{21}$ E. Bloustein. Privacy as an Aspect of Human Dignity: An Answer to Dean Prosser. New York University Law Review 1964; 39: 962-1007.

${ }^{22}$ C. Fried. 1970. An Anatomy of Values. Cambridge. Harvard University Press.

${ }^{23}$ W. A. Parent. Op.cit., note 19.

${ }^{24}$ A. L. Allen. Op. cit., note 10, p. 31

${ }^{25}$ A. F. Westin. 1994. Privacy and Genetic Information. In The Genetic Frontier: Ethics, Law, and Policy. M. S. Frankel and A. H. Teich, eds. Washington, D. C. American Association for the Advancement of Science: 53-76, p. 54.

${ }^{26}$ A. L. Allen. Op.cit., note 10, p. 34

${ }^{27}$ M. A. Rothstein et al. The Expanding Use of DNA in Law Enforcement: What Role for Privacy? Journal of Law, Medicine \& Ethics 2006: 153-164, p. 160.

${ }^{28}$ N. Rose. 2007. The Politics of Life Itself: Biomedicine, Power, and Subjectivity in the Twenty-First Century. Princeton. Princeton University Press. 
${ }^{29}$ R. F. Chadwick et al. 1997. The right to know and the right not to know. Aldershot. Ashgate; R. Andorno. The right not to know: an autonomy based approach. Journal of Medical Ethics 2004; 30: 435-440.

${ }^{30}$ M. G. Weiss. 2009. Die Auflösung der menschlichen Natur. In Bios und Zoë. Die menschliche Natur im Zeitalter ihrer technischen Reprodizierbarkeit. M. G. Weiss, ed. Frankfurt/M. Suhrkamp, p. 34-55.

31 A. Harmon. Cancer Free at 33, but Weighing a Mastectomy. The New York Times 16 November 2007.

32 A. T. Wilingham et al. TUF love for "junk" DNA. Cell 2006; 125: 1215-1220.

${ }^{33}$ A. M'Charek. Silent witness, articulate collective: DNA evidence and the inference of visible traits. Bioethics 2008; Vol. 22, No. 9: 519-528. I owe this insight to one of the anonymous reviewers of Genomics, Society and Policy.

${ }^{34}$ T. L. Beauchamp et al. 1994. Principles of Biomedical Ethics. $4^{\text {th }}$ edition. New York. Oxford University Press; U.S. President's Commission for the Study of Ethical Problems in Medicine and Biomedical and Behavioral Research. 1982. Making Health Care Decisions: A Report on the Ethical and Legal Implications of Informed Consent in the Patient-Practitioner Relationship. 3. vols. Washington D. C.; S. Wear et. al. 1997. Informed Consent: Patient Autonomy and Clinician Beneficence Within Health Care. Washington D. C. Georgetown University Press.

${ }^{35}$ www.proasyl.de/de/themen/rechtspolitik/stellungnahmen/2010/gendiagnostikgesetz/ (accessed 18 November 2011).

${ }^{36}$ G. P. Murdock. 1949. Social Structure. New York. Macmillan; D. D. Meyer. Parenthood in a Time of Transition: Tensions between Legal, Biological, and Social Conceptions of Parenthood. The American Journal of Comparative Law 2006; 54: 125-144.

${ }^{37}$ Th. Lemke et al., op.cit. note 8 .

${ }^{38}$ D. D. Meyer. Op. cit., note 36.

${ }^{39}$ T. R. Murdock. Op.cit., note 8.

${ }^{40}$ D. D. Meyer. Op. cit., note 36, p. 126.

${ }^{41}$ Th. Lemke et al. Op.cit. note 8 .

42 J. Butler. 2006. Gender Trouble. Feminism and the Subversion of Identity. New York. Routledge.

${ }^{43}$ C. Charles. 2003. The Sharon Kowalski Case: Lesbian and Gay Rights on Trial. Lawrence. University Press of Kansas.

${ }^{44}$ J. Butler. 2000. Antigone's Claim: Kinship between Life and Death. New York. Columbia University Press.

${ }^{45}$ T. R. Murdock. Op. cit., note 8, p. 1511.

46 B. Prainsack et al. Personal genomes: Misdirected precaution. Nature 2008; 456: 34-35.

47 A. Petryna. 2002. Biological Citizens after Chernobyl. Princeton. Princeton University Press.

48 A. Kerr. Genetics and Citizenship. Society 2003; 40(6): 44-50.

${ }^{49}$ D. D. Meyer. Op. cit., note 36, p. 134.

${ }^{50}$ Ibid., p. 135.

${ }^{51}$ Ibid.

${ }^{52}$ J. D. Villiers, Op.cit., note 8, p. 264.

${ }^{53}$ D. D. Meyer. Op. cit., note 36, p. 131

${ }^{54} \mathrm{Ch}$. Thompson. Skin Tone and the Persistence of Biological Race in Egg Donation for Assisted Reproduction. In Shades of Difference: Why Skin Color Matters. E. Nakano Glenn ed. Stanford. Stanford University Press: 131-148.

${ }^{55}$ Formerly "if a presumed father did not come to doubt his status as the biological father until some years after the child's birth, however, most courts were reluctant to allow the man to abandon his role as father. [...] Recently [...] a small but growing number of courts and legislatures have changed course. $[\ldots]$ These courts and legislatures have moved to allow men to discard their status as father upon proof of genetic non-paternity.” D. D. Meyer. Op. cit., note 36, p. 138.

${ }^{56}$ Ibid p. 141.

${ }^{57}$ Ibid p. 139.

58 "With its increased use, particularly towards the latter part of the $20^{\text {th }}$ century, there was growing dispute about the secrecy inherent to donor insemination; both Victoria (Australia) and Sweden moved to legislate, in 1984 and 1985 respectively, to remove donor anonymity. Similar laws have since been 
passed in countries such as Austria, Germany, Switzerland, The Netherlands, Norway, New Zealand and the UK." L. Turney. The making and breaking of paternity secrets in donor insemination. Journal of Medical Ethics 2010; 36: 401-406, p. 402.

${ }^{59}$ Ibid, p.403. And Turney goes on: "Genetic medicine and the promise of finding, curing and eradicating disease and its causes have placed a pervasive new emphasis on biological relationships. There is an imperative to know genetic heritage because how we are related to someone is no longer understood in reference to 'blood' and 'blood lines' but to genes. In this reckoning, the genitor becomes much more central to identity because he provides the genetic substance of fully half of who we are. ... The genitor can no longer be ignored as he now has a symbolic and material place in the child's life schema. It has thus become ethically and morally problematic to withhold knowledge about him as there are no counter arguments to the autonomous right to truth when it comes to health, identity and heritability. Where health and genealogical connectedness become paramount, paternity secrets are no longer seen to be protective; instead, they are viewed as damaging and deceitful.".

${ }^{60}$ Ibid.

${ }^{61}$ Ibid p. 404

62 Deutscher Ethikrat. 2009. Anonymous relinquishment of infants: tackling the problem. Berlin, p. 62. ${ }^{63}$ H. Sussebach. Ich will wissen, wer er ist. Die Zeit 2010; October 14: 17-19.

${ }^{64}$ L. Turney. op. cit., note 58, p. 404.

${ }^{65}$ P. Rabinow. 1999. Artificiality and Enlightenment: From sociobiology to biosociality. In The science studies reader. M. Bagioli, ed. New York. Routledge: 407-416.

${ }^{66}$ A. Petryna. Op. cit., note $47 .$.

${ }^{67}$ J. Butler. Op. Cit., note $42 .$.

${ }^{68}$ N. Rose. Op. Cit., note 28.

${ }^{69}$ Ibid., p. 69.

${ }^{70}$ Gendiagnostikgesetz $\S 17$, para. 8 .

${ }^{71}$ E. Husserl. 1970. The Crisis of European Sciences and Transcendental Phenomenology. Evanston. Northwestern University.

${ }^{72}$ T. R. Murdock. Op. cit., note 8, p. 1533. 